\title{
Larvicidal Activity of Inorganic Salts Against Anopheles Stephensi and Culex Quinquefasciatus
}

\author{
Nsimba Z.F. ${ }^{1 *}$, Bobanga L.T. ${ }^{2}$, Kabututu Z.P. ${ }^{1}$, Liesse I.J.M. ${ }^{3}$ \\ ${ }^{1}$ Department of Basic Sciences, Faculty of Medicine, University of Kinshasa P.B.127 Kinshasa XI, Democratic \\ Republic of Congo \\ ${ }^{2}$ Department of Tropical Medicine, Faculty of Medicine, University of Kinshasa P.B.127 Kinshasa XI, \\ Democratic Republic of Congo \\ ${ }^{3}$ Laboratory of Experimental and Pharmaceutical Microbiology, Faculty of Pharmaceutical Sciences, \\ University of Kinshasa P.B.127 Kinshasa XI, Democratic Republic of Congo \\ * Corresponding author email: zakanda.nsimba@unikin.ac.cd
}

Received: 30 June 2020 / Accepted: 22 August 2020 / Published: 04 September 2020

\begin{abstract}
Mosquitoes transmit serious human diseases, causing millions of deaths worldwide every year and the development of resistance to chemical insecticides resulting in rebounding vectorial capacity. In this study, the larvicidal bioassays for activities of aqueous solutions of weak acid $\left[\left(\mathrm{NH}_{4}\right)_{2} \mathrm{SO}_{4}\right.$ and $\mathrm{NaH}_{2} \mathrm{PO}_{4}$ and weak base $\left(\mathrm{Na}_{2} \mathrm{CO}_{3}\right.$ and $\left.\mathrm{NaHCO}_{3}\right)$ inorganic salts against late instar larvae of disease vectors Anopheles stephensi and Culex quinquefasciatus were carried out under laboratory settings. The four inorganic salts showed varied levels of larvicidal activities after $24 \mathrm{~h}$-exposure on Anopheles stephensi and Culex quinquefasciatus larvae in a dose-dependent fashion. However, the larvicidal activities were relatively higher in $\mathrm{Na}_{2} \mathrm{CO}_{3}\left(\mathrm{LC} 50=3162\right.$ and $447 \mathrm{ppm}$ ) and $\mathrm{NaHCO}_{3}(\mathrm{LC} 50=5623$ and $398 \mathrm{ppm})$ solutions as compared to those in $\left(\mathrm{NH}_{4}\right)_{2} \mathrm{SO}_{4}(\mathrm{LC} 50=7943$ and $1995 \mathrm{ppm})$ and $\mathrm{NaH}_{2} \mathrm{PO}_{4}(\mathrm{LC} 50=7943$ and $7120 \mathrm{ppm})$. The present study showed that the inorganic salts $\mathrm{Na}_{2} \mathrm{CO}_{3}$, $\mathrm{NaHCO}_{3},\left(\mathrm{NH}_{4}\right)_{2} \mathrm{SO}_{4}$ and $\mathrm{NaH}_{2} \mathrm{PO}_{4}$ could serve as potential larviciding agents considering their low toxicity. Therefore, this study provides a first report on the larvicidal activity of the inorganic salts on mosquito larvae of disease vectors.
\end{abstract}

Keywords: Inorganic salts, Larvicidal activity, Anopheles stephensi, Culex quinquefasciatus.

\section{Introduction}

Many insects transmit to humans a very wide variety of microbes and parasites, many of which can be pathogenic. Mosquitoes are the largest group of insects that can transmit pathogens to humans [1]. They belong to three genera, Aedes, Anopheles and Culex and are responsible of more than $17 \%$ of all infectious diseases [2]. Infectious diseases transmitted by these vectors are the best known (malaria, dengue, filariases, yellow fever...) and have a considerable impact on human and animal health, as well as on the economy of human societies [3, 4].

Each year, there are over a billion cases and over a million deaths worldwide due to diseases such as malaria [2, 4], which puts half of the world's population at risk. However, malaria major impact is almost entirely on developing countries, especially in sub-Saharan Africa [5] where malaria is the main cause of morbidity and mortality with children under the age of five being the most affected age category [6, 7].

In this region, Plasmodium falciparum is the most prevalent malaria parasite, accounting for $99.7 \%$ cases [8] and is transmitted by mosquitoes of the genus Anopheles. Among the near 128 Anopheles species found in Africa, Anopheles gambiae sensu stricto, Anopheles coluzzii and Anopheles funestus sensu stricto are the most efficient in malaria transmission mainly in rural areas of sub-Saharan Africa where the disease is most prevalent with strong seasonal variations. 
As for Anopheles stephensi, they are also found in rural areas, but are getting increasingly established in urban areas where they breed in water containers from human activities [9].

Culex quinquefasciatus is part of the genus Culex, which contains several known mosquito vectors of pathogens such as filaria and flaviviruses [10]. Culex quinquefasciatus readily feeds on avian, mammalian or human hosts. Its larvae are typically found in artificial containers of water or man-made impoundments including open ponds, pools, canals, lagoons, ditches and drains containing human or animal sewage. Culex quinquefasciatus has a worldwide distribution mostly in tropical and subtropical regions, playing a major role in the transmission of human diseases of medical importance such as the disabling lymphatic filariasis throughout SouthEast Asia, Africa, South America and the Caribbean, as well as the Saint Louis Encephalitis Virus (SLEV) and the West Nile Virus (WNV) in the southern United States and Mexico [11, 12]. The burden of these diseases on the affected populations is heavy not only in terms of morbimortality and lifelong disabilities associated with social stigma but also the negative impact on the economy of the concerned countries [13]. In addition, the nuisance associated with Culex quinquefasciatus biting constitutes an important nocturnal discomfort [14].

Several drugs have been effectively used to deal with mosquito-borne diseases. However, pathogen resistance to several drugs has hampered treatment strategies. Therefore, prophylactic measures including vector control have become an essential part of the overall control strategy $[6,15]$ even as the therapeutic component remains fundamental.

Several methods, passive or active, individual or community-based, biological or chemical have been used by humans to fight against mosquitoes involved in disease transmission. The most effective approach to mosquito control remains that based on the elimination, if not the sufficient reduction of larval mosquito populations, given that at this developmental stage, mosquitoes occupy a minimum geographical space that is most easily located and controllable [16]. Since mosquito larvae have an aquatic life, chemical control remains the major means and increasingly calls for selective products, which must take environment imperatives into account [4, 17]. However, some products used as larvicides (motor oil, petroleum, insecticides...) are toxic and polluting while others cause development of resistance in mosquitoes $[4,18]$. Hence the need to look for new larvicidal molecules with low risk to humans and the environment.

The objective of the present study was to evaluate the response of mosquito larvae of Anopheles stephensi, an urban malaria vector and Culex quinquefasciatus, a filarial vector in solutions of inorganic salts, namely sodium carbonate $\left(\mathrm{Na}_{2} \mathrm{CO}_{3}\right)$, sodium bicarbonate $\left(\mathrm{NaHCO}_{3}\right)$, sodium dihydrogen phosphate $\left(\mathrm{NaH}_{2} \mathrm{PO}_{4}\right)$ and ammonium sulfate $\left[\left(\mathrm{NH}_{4}\right)_{2} \mathrm{SO}_{4}\right.$.

\section{Materials and Methods}

\subsection{Chemicals}

All reagents used [sodium carbonate $\left(\mathrm{Na}_{2} \mathrm{CO}_{3}\right)$, sodium bicarbonate $\left(\mathrm{NaHCO}_{3}\right)$, sodium dihydrogen phosphate $\left(\mathrm{NaH}_{2} \mathrm{PO}_{4}\right)$ and ammonium sulfate $\left.\left(\mathrm{NH}_{4}\right)_{2} \mathrm{SO}_{4}\right]$ were obtained from Sigma Chemicals Co. (St. Louis, MO, USA). They were of analytical grade and were used without further purification. The deionized water was employed as solvent throughout the experiments.

\subsection{Preparation of inorganic salt solutions}

The inorganic salt solutions were prepared with deionized water. The concentrations of the solutions were classified in arithmetic progression so as to obtain a range of concentrations, depending on the sensibility of the larvae to the chosen salt, which kill between 0 and $100 \%$ of individuals. Five different concentrations were selected for each salt.

\subsection{Mosquito larvae capture and culture}

The mosquito larvae used in this study were collected during the months of March and April of the year 2019, in stagnant waters of plots located in the Mokali district in the municipality of Kimbanseke and in ponds located at the Monastery in the municipality of Mont-Ngafula 
in the city of Kinshasa, Democratic Republic of Congo.

The larvae have been identified as Anopheles stephensi or Culex quinquefasciatus in the Department of Tropical Medicine of the Faculty of Medicine of the University of Kinshasa. They were kept and reared in plastic basins containing water from the environment where they were collected.

\subsection{Larvicidal bioassay}

The test of the larvicidal effects of inorganic salt aqueous solutions against mosquito larvae Anopheles stephensi and Culex quinquefasciatus was conducted in accordance with the World Health Organization (WHO) standard method [19]. Briefly, 25 larvae of third and fourth instars were rinsed with deionized water and placed on a $500 \mathrm{ml}$ porcelain bowl containing $250 \mathrm{ml}$ of aqueous solution of given concentration of each salt (Figure 1). The larvae exposed to deionized water without inorganic salt served as control. The number of dead larvae was counted after 24 $\mathrm{h}$ of exposure and the percentage of mortality was reported from the average of four replicates. At the end of $24 \mathrm{~h}$, the larvae were considered dead as they showed no sign of swimming movements even after gentle touching with a glass rod, as described in the WHO technical report series. All the experiments were carried out at room temperature of $28 \pm 1.3^{\circ} \mathrm{C}$.

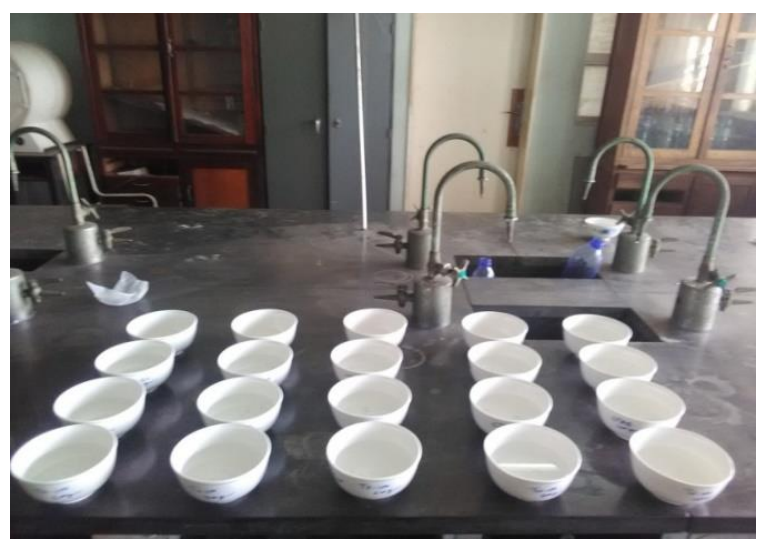

Fgure1: Illustration of the larvicidal assay showing bowls containing each 25 larvae in $250 \mathrm{ml}$ solution for a given inorganic salt in five different concentrations (lines). Each concentration was repeted four times (culumns)

\subsection{Statistical analysis}

The average larval mortality data were subjected to probit analysis for calculating LC50 (lethal concentrations that kill $50 \%$ of individuals) and LC90 (lethal concentrations that kill 90\% of individuals) values and their statistics at 95\% confidence limits of LCL (lower confidence limit) and UCL (upper confidence limit) values were estimated by fitting a probit regression model. All the analyses were calculated using the SPSS version 16.0 for Windows. Results with $\mathrm{p}<0.05$ were considered to be statistically significant.

\section{Results}

The results for the larvicidal activity of the inorganic salt aqueous solutions against Anopheles stephensi and Culex quinquefasciatus larvae are summarized in Table 1 while the LC50 and LC90 values of the inorganic salts are found in Table 2.

Table 1: Larvicidal activity of aqueous solutions of inorganic salts.

\begin{tabular}{|c|c|c|}
\hline \multirow{2}{*}{$\begin{array}{c}\text { Concentration } \\
(\mathbf{p p m})\end{array}$} & \multicolumn{2}{|c|}{ \% Larval mortality after $24 \mathrm{~h}$} \\
\hline & Anopheles & Culex \\
\hline \multicolumn{3}{|l|}{$\mathrm{Na}_{2} \mathrm{CO}_{3}$} \\
\hline 600 & $20.00 \pm 0.00$ & $61.65 \pm 12.55$ \\
\hline 1600 & $28.35 \pm 2.85$ & $69.45 \pm 5.75$ \\
\hline 2600 & $46.65 \pm 12.55$ & $80.20 \pm 2.85$ \\
\hline 3600 & $76.65 \pm 7.70$ & $91.65 \pm 14.40$ \\
\hline 5000 & $91.65 \pm 2.85$ & $100.00 \pm 0.00$ \\
\hline \multicolumn{3}{|l|}{$\mathrm{NaHCO}_{3}$} \\
\hline 600 & $5.75 \pm 3.35$ & $60.00 \pm 0.00$ \\
\hline 2200 & $18.35 \pm 2.85$ & $80.00 \pm 0.00$ \\
\hline 3800 & $28.35 \pm 2.80$ & $86.65 \pm 2.80$ \\
\hline 5400 & $43.30 \pm 5.70$ & $88.35 \pm 2.75$ \\
\hline 7000 & $71.65 \pm 2.85$ & $99.66 \pm 2.85$ \\
\hline \multicolumn{3}{|l|}{$\left(\mathrm{NH}_{4}\right)_{2} \mathrm{SO}_{4}$} \\
\hline 5000 & $21.65 \pm 2.85$ & $85.00 \pm 0.00$ \\
\hline 7000 & $35.00 \pm 5.00$ & $86.70 \pm 2.75$ \\
\hline 9000 & $51.65 \pm 0.57$ & $95.00 \pm 2.80$ \\
\hline 11000 & $58.25 \pm 7.65$ & $100.00 \pm 0.00$ \\
\hline 13000 & $70.00 \pm 5.50$ & $100.00 \pm 0.00$ \\
\hline \multicolumn{3}{|l|}{$\mathrm{NaH}_{2} \mathrm{PO}_{4}$} \\
\hline 5000 & $26.60 \pm 15.25$ & $33.35 \pm 10.40$ \\
\hline 7000 & $48.35 \pm 10.40$ & $50.00 \pm 5.00$ \\
\hline 9000 & $60.00 \pm 7.05$ & $66.65 \pm 7.60$ \\
\hline 11000 & $81.65 \pm 7.60$ & $85.00 \pm 5.00$ \\
\hline 13000 & $95.00 \pm 5.00$ & $98.35 \pm 1.57$ \\
\hline
\end{tabular}

Control - Nil mortality; Data are presented as mean \pm SD; Mean value of four replicates; Significant at $\mathrm{p}<0.05$ level. 
The potential larvicidal activity of the four inorganic salts was noted and varied in dosedependent manner in all cases for both species of larvae. The larval mortality of the sodium carbonate salt $\left(\mathrm{Na}_{2} \mathrm{CO}_{3}\right)$ aqueous solutions ranged from 20.00 to $91.65 \%$ and from 61.65 to $100.00 \%$ for Anopheles and Culex larvae, respectively at doses ranging from 600 to 5000 ppm. From this range, the LC50 values were estimated at 3162 and $447 \mathrm{ppm}$ for Anopheles and Culex larvae, respectively while the LC90 were estimated at 4731 and $3548 \mathrm{ppm}$ for Anopheles and Culex larvae, respectively.

Larvicidal activity of the sodium bicarbonate $\left(\mathrm{NaHCO}_{3}\right)$ aqueous solutions was observed at doses ranging from 600 to $7000 \mathrm{ppm}$, and the larvicidal mortality ranged from 5.75 to 71.65 and 60.00 to $96.66 \%$. From this range of the larval mortality, the LC50 was estimated at 5623 ppm for the anopheles larvae and $398 \mathrm{ppm}$ for the Culex larvae while the LC90 was estimated at 11220 and 5623 ppm, respectively.

While the larval mortality of the sulfate ammonium salt $\left[\left(\mathrm{NH}_{4}\right)_{2} \mathrm{SO}_{4}\right]$ aqueous solutions ranged from 21.65 to $70.00 \%$ and 85.00 to $100.00 \%$ respectively for the Anopheles and Culex larvae at doses ranging from 5000 to 13000 ppm, the resulting LC50 were 7943 and 1995 ppm and LC90 were 25119 and 7079 ppm for the Anopheles and Culex larvae, respectively.

At the same range of doses, the larval mortality of the sodium dihydrogen phosphate salt $\left(\mathrm{NaH}_{2} \mathrm{PO}_{4}\right)$ aqueous solutions were estimated at
26.60 to 95.00 and 33.35 to $98.32 \%$ for the Anopheles and Culex larvae, respectively. The LC50 was estimated at $7943 \mathrm{ppm}$ for the Anopheles larvae and 7120 ppm for the Culex larvae while the LC90 was estimated at 11220 ppm for the both species of larvae. Note that no larval mortality was observed in the negative control containing deionized water without inorganic salt.

\section{Discussion}

Vector control using natural product pesticides is highly preferred than conventional pesticides because of their rapid environmental degradation and low-toxicity to other organisms. However, isolation and chemical characterization of the active compounds from plants with strong biological activities can be a tedious process compared to synthesizing new synthetic compounds because natural compounds are generally isolated in small amounts, with a purity highly variable depending upon the extraction method, plant part, geographical origin and location, climate and the overall growth and health of the plant from which the chemical is extracted [20]; in addition, the repellency and duration of times are usually unsatisfactory [21]. The inorganic salts investigated in the present study have multiple uses in human, industry and scientific research: $\mathrm{Na}_{2} \mathrm{CO}_{3}$, an approved food additive, is an alkaline reagent and consequently has some potential for improving the rehydration behavior of milk protein isolate powder [22].

Table 2: LC50 and LC90 values of the inorganic salts against Anopheles stephensi and Culex quinquefasciatus larvae.

\begin{tabular}{|c|l|c|c|}
\hline Inorganic salts & Spicies & $\begin{array}{c}\text { LC50, ppm } \\
(\mathbf{9 5 \%} \text { confidence limit })\end{array}$ & $\begin{array}{c}\text { LC90, ppm } \\
\text { (95\% confidence limit) }\end{array}$ \\
\hline $\mathbf{N a}_{2} \mathbf{C O}_{3}$ & Anopheles & $3,162(3100-3224)$ & $4,731(4,638-4,824)$ \\
\cline { 2 - 4 } & Culex & $447^{\mathrm{a}}(438-456)$ & $3,548^{\mathrm{a}}(3,478-3,618)$ \\
\hline \multirow{2}{*}{$\mathbf{N a H C O}_{3}$} & Anopheles & $5,623(5,513-5,733)$ & $11,220(11,000-11,440)$ \\
\cline { 2 - 4 } & Culex & $398^{\mathrm{b}}(390-406)$ & $5,623^{\mathrm{b}}(5,513-5,733)$ \\
\hline \multirow{2}{*}{$\left.\mathbf{N H}_{4}\right)_{2} \mathbf{S O}_{4}$} & Anopheles & $7,943(7,787-8,099)$ & $25,119(24,637-25,611)$ \\
\cline { 2 - 4 } & Culex & $1,995(, 1956-2,034)$ & $7,079(6,940-7,218)$ \\
\hline \multirow{2}{*}{$\mathbf{N a H}_{2} \mathbf{P O}_{4}$} & Anopheles & $7,943(7,787-8,099)$ & $11,220(11,000-11,440$ \\
\cline { 2 - 4 } & Culex & $7,120(6,980-7,260)$ & $11,220(11,000-11,440)$ \\
\hline
\end{tabular}

LC50 and LC90 - Lethal concentrations that kills 50 and $90 \%$ of the exposed larvae; ${ }^{\text {a,b }}$ Inorganic salts with highest efficacy as shown by relatively low LC50 and LC90 values. 
Nsimba et al., Int. Ann. Sci.; Vol. 10, Issue 1, pp: 45-51, 2021

$\mathrm{NaHCO}_{3}$ has become the salt of preferential use in meat industry during recent years because it improve meat quality [23] and is also used in therapy for critically ill patients with metabolic acidosis [24]; $\left(\mathrm{NH}_{4}\right)_{2} \mathrm{SO}_{4}$, a low-cost and recyclable chemical agent, is used in the extraction/purification of proteins, in agriculture as nitrogen fertilizer $[25,26]$; while $\mathrm{NaH}_{2} \mathrm{PO}_{4}$ is an important component of normal human cells, critical to health and necessary part of the human diet; also used in a range of foods, to enhance processing, organoleptic quality and safety [27].

For the present study, the aqueous solutions of inorganic salts investigated showed toxic effect on Anopheles stenphensi and Culex quinquefasciatus larvae after $24 \mathrm{~h}$ of exposure, depending on the salt and the concentration (Tables 1); there was no mortality in control after $24 \mathrm{~h}$ of exposure. The weak acid characteristic of $\left(\mathrm{NH}_{4}\right)_{2} \mathrm{SO}_{4}$ and $\mathrm{NaH}_{2} \mathrm{PO}_{4}$ and the weak base characteristic of $\mathrm{Na}_{2} \mathrm{CO}_{3}$ and $\mathrm{NaHCO}_{3}$ may be responsible for the larvicidal activities of these inorganic salts; because no mortality of Anopheles stephensi and Culex quinquefasciatus larvae was observed with the neutral inorganic salts sodium chloride $(\mathrm{NaCl})$ and sodium phosphate $\left(\mathrm{Na}_{3} \mathrm{PO}_{4}\right)$ aqueous solutions, even at doses 10 times higher than those tested for the weak acid and weak base inorganic salts (data no shown).

Previous studies found that inorganic salts have very interesting antimicrobial [28, 29], fungicide (especially $\mathrm{Na}_{2} \mathrm{CO}_{3}$ and $\mathrm{NaHCO}_{3}$ ) [30, 31] and insecticide properties [32]. Darriet et al. [33] also found that mineral and organic compounds have an impact on the development of larvae because the NPK fertilizer placed in water killed all the Aedes Aegypti larvae before pupation.

In general, Culex quinquefasciatus larvae were more sensitive to salt solutions compared to those of Anopheles stephensi, in all cases. The same trend was observed by Mathew et al. [34] and Sukhthankar et al. [35] with the extract of Nyctanthesaror-tristisand and the extract of Chromolaena odorata leaves, respectively, for the same species of larvae. And both species of larvae were more sensitive to weak base salt $\mathrm{Na}_{2} \mathrm{CO}_{3}$ and $\mathrm{NaHCO}_{3}$ solutions (concentrations from 600 to $5.000 \mathrm{ppm}$ and from 600 to $7.000 \mathrm{ppm}$, respectively) than weak acid salt solutions $\left(\mathrm{NH}_{4}\right)_{2} \mathrm{SO}_{4}$ and $\mathrm{NaH}_{2} \mathrm{PO}_{4}$ (concentrations from 5.000 to 13.000 ppm for both salts) (Tables 1 and 2).

\section{Conclusion}

We found from the present study that the weak acid and weak base inorganic salts $\mathrm{Na}_{2} \mathrm{CO}_{3}$, $\mathrm{NaHCO}_{3},\left(\mathrm{NH}_{4}\right)_{2} \mathrm{SO}_{4}$ and $\mathrm{NaH}_{2} \mathrm{PO}_{4}$ possess potent larvicidal activities against mosquitoes Anophele stephensi and Culex quinquefasciatus larvae. These salts could be a basis for search for larvicidal compounds, thus constituting an interesting approach for effective control of disease-transmitting vector mosquitoes due to their low toxicity.

\section{Declarations}

\subsection{Acknowledgements}

The author would like to acknowledge Mr L.B.N. Tusamba for his help in collecting mosquito larvae and Mr D.N. Koy for providing the necessary technical assistance (all from Service of Biochemistry, Department of Basic Sciences, Faculty of Medicine and University of Kinshasa).

\subsection{Competing Interests}

The authors declare that the research was conducted in the absence of any commercial or financial relationship that could be construed as a potential conflict of interest.

\section{How to Cite this Article:}

Nsimba et al. "Larvicidal Activity of Inorganic Salts Against Anopheles Stephensi and Culex Quinquefasciatus", Int. Ann. Sci., vol. 10, no. 1, pp. 45-51, Sep. 2020 .

\section{References}

[1] M. M. Jolyon, M. Kayleigh, F. Schaffner, V. Versteirt, G. Hendrickx, H. Zeller, and W.V. Bortel, "A Review of the Invasive Mosquitoes in Europe: Ecology, Public Health Ricks, and Control Options", Vector Borne and Zoonotic Dis., vol. 12, no 6, pp. 435-447, 2012. https://doi.org/10.1089/vbz2011.0814

[2] R. E. Cibulskis, P Alonso, J Aponte, M. Aregawi, A. Barrette, L. Bergeron, C. A. Fergus, T. Knox, M. Lynch, E. Patouillard, S. Schwarte, , S. Stewart, R. Williams, "Malaria: global progress 2000-2015 and future challenge", Infect. Dis. Poverty, vol. 5, no. 1, pp. 61-68, 2016. https://doi.org/10.1186/s40249-016-0151-8

[3] J. N. Goesch, N. G. Schwarz, M. L. DeckerL, S. Oyakhirome, L. B. Borchert, U. D. Kombila, M. Poetschke, B. Lell, S. Issifou, P. G. Kremsner and M. P. 
Grobusch, "Socio-economic status is inversely related to bed net use in Gabon". Malar. J., vol. 7, no. 1, pp. 60-67, 2008. https://doi.org/10.1186/1475-2875-60

[4] N. Soltani, "Les moustiques: risques sanitaires, bio essais et stratégies de contrôle", Conférence : $1^{\mathrm{er}}$ séminaire national sur l'entomologie médicale et la lutte biologique, Tébessa, Algérie, 19-20 Oct. 2015. https://doi.org/10.13140/RG.2.1.2215.5606

[5] M. P. Cilundika, N. O. Nsenga, O. N. Luboya, "Problématique de l'utilisation des Moustiquaires imprégnées d'insecticide à longue durée (MIILD) chez les enfants de moins de 5 ans en République Démocratique du Congo". Pan Afr. Med. J., vol. 23, pp. 101 -

2016. https://doi.org/10.11604/pamj.2016.23101.7050

[6] A. Bawah, F. N. Binka, "How many years of life could be saved if malaria were eliminated from a hyperendemic area of Nothern Ghana?", Am. J. Trop. Med. Hyg., vol. 77, no. 6, pp. 145-152, 2007

[7] N. Dhinga, P. Jha, V. P. Sharma, A. A. Cohen, R. M. Jotkar, others, "Adult and child malaria mortality in India : a nationally representative mortality survey", The Lancet, vol. 376, no. 9754, pp. 1768-1774, 2010

[8] S. Chibuta, A. C. Acar, "Real-time malaria parasite screening in thick blood smears for low-resource setting", J. Digit. Imaging, vol. 33, pp. 763-775, 2020. https: //doi.org/10.1007/s10278-018-00284-2

[9] W. Takken, S. Lindsay, "Increased threat of urban malaria from Anopheles stephensi mosquitoes, Africa", Emerg. Infect. Dis., vol. 25, no. 7, pp. 1431-1433, 2019. https://doi.org/10.3201/eid2507.190301

[10] F. Tandina, O. Doumbo, A.S. Yaro, S. F. Traoré, P. Parola, V. Robert, "Mosquitoes (Diptera: Culicidae) and mosquito-borne diseases in Mali, West Africa", Parasit. Vectors, vol. 11, no. 1, pp. 467, 2018. http://doi.org/10.1186/s13071-018-3045-8

[11] L. B. Goddard, A. E. Roth, W. K. Reisen, T. W. Scott, "Vector competence of California mosquitoes for West Nille virus", Emerg. Infect. Dis., vol. 8, no. 12, pp. 13851391, 2002. https: //doi.10.3201/eid0812.020536

[12] R. P. Meyer, J. L. Hardy, S. B. Presser, "Comparative vector competence of Culex tarsalis and Culex quinquefasciatus from the coachella, imperial, and San Joaquin Valley of California for St. Louis encephalitis virus", Am. J. Trop. Med. Hyg., vol. 32, no. 2, pp. 305311,1983

[13] W. R. Shaw, F. Catteruccia, "Vector biology meets disease control: using basic research to fight vectorborne diseases", Nat Microbiol, vol. 4, no. 1, pp. 20-34, 2019. https://doi.org/10.1038/s41564-018-0214-7

[14] E. C. Uttah, G. N. Wokem, C. Okonofua, "The abundance and biting patterns of Culex quinquefasciatus Say (Culicidae) in the Coastal region of Nigeria", ISRN Zool., vol.. 2013, Article ID 640691,7 p. http://dx.doi.org/10.1155/2013/640691

[15] J. N. Govella, P. P. Chaki, F. Gerry, G. F. Killen, "Entomological surveillance of behavioural resilience and resistance in residual malaria vector populations", Malar. J., vol. 12, pp. 124- , 2013. https://doi.org/10.1186/1475-2875-12-124

[16] M. E. Joubari, A. Louah, O. Himmi, "Les moustiques (Diptera, Culicidae) des marais de Smir (Nord-Ouest du Maroc): inventaire et biotype", Bull. Soc. Pathol. Exot., vol. 107, pp. 48-59, 2014. https://doi.org/10.1007/s13149-014-0327-4
[17] J. E. Casida, G. B. Quistad, "Golden age of insecticide research: past, present, or future?" Annu. Rev. Entomol., vol. 43, pp. 1-16, 1998. https://doi.org/10.1146/annurev.ento.43.1.1

[18] S. Kumar, M K. K. Pillai, Correlation between the reproductive potential and the pyrethroid resistance in an Indian strain of filarial vector, Culex quinquefasciatus Say (Diptera: Culidae), Bull. Entomol. Res., vol. 101, pp. 25-31. https://doi.org/10.1017/S0007485310000131

[19] World Health Organization, "Guidelines for laboratory and field testing of mosquito larvicides", WHO/CDC/WHOPES/GCDPP, 13, pp. 10-12, 2005. https://www.scirp.org

[20] R. S. Mann and P. E. Kaufman, "Natural product pesticides: their development, delivery and use against insect vectors". Mini-Rev. Org. Chem., vol. 9, no. 2, pp. 185-202,

2012. https://doi.org/10.2174/157019312800604733

[21] S. Liao, Y. Liu, Z. Xiao, G. Fan, S. Chen, P. Wang, Z. Wang, "Hydronopylformamides: Modification of the naturally occurring compound (-)- $\beta$-pinene to produce insect repellent candidates against Blattella germanica", Molecules, vol. 22, no. 6, pp. 1004. https://doiorg/10.3390/molecules 22061004

[22] S. Wu, J. Fitzpatrick, K. Cronin, S. Miao, "Effect of sodium carbonate on the rehydration of milk protein isolate powder", Food Hydrocoll., vol. 99, 2020. https://doi.org/10.1016/j.foodhyd.2019.105305

[23] R. Sen, B. M. Naveena, M. Muthukumar, Y. Babji, T. R. K. Murthy, "Effect of chilling, polyphosphate, and bicarbonate on quality characteristics of broiler breast meat", Br. Poult. Sci., vol. 46, no. 4, pp. 451-456, 2005. https://doi.org/10.1080/00071660500191072

[24] F. Tomoko, U. Andrew, E. Licari, L. Romero, R. Bellomo, "Sodium bicarbonate therapy for critically ill patients with metabolic acidosis: a scoping and systematic review", J. Crit. care, vol. 51, pp. 184-191, 2019. https://doi.org/10.1016/j.jcrc.2019.02027

[25] K. Y. Ko, D. U. Ahn, "Preparation of immunoglobulin Y from egg Yolk using ammonium sulphate precipitation and ion exchange chromatography", Poult. Sci., vol. 86, no. 2, pp. 400-407, 2007. https://doi.org/10.1093/ps/86.2.400

[26] Y. Miah, S. Kanazawa, M. Chino, "Nutrient distribution across wheat rhizophere with oxamide and ammonium sulfate as N source", Soil Sci. Plant Nutr., vol. 44, no. 4, pp. 579-587, 1998. https://doi.org/10.1080/00380768.1998.10414481

[27] G. A. Dykes, R. Coorey, J. T. Ravensdale, A. Sarjit, "Phosphates", Ency. Food Chem., pp. 218-224, 2019. https://doi.org/10.1016/B978-0-08-100596-5.21583-7

[28] L. Polo, B. D. Grenu, E. D. Bella, S. Pagani, , P. Torricelli, J. L. Vivancos, M. Ruiz-Rico, J. M. Barat, E. Aznar, R. Martinez-Manez, M. Fini, F. Sancenon, "Anitmincrobial activity of commercial calcium phosphate based materials functionalized with vanillin", Acta Biomater., vol. 81, pp. 293-303, 2018. https:/doi.org/10.1016/j.actbio.2018.09.033

[29] R. C. Gonçalves, D. P. Silva, R. Signini, P. L. F. Naves, "Inhibition of bacterial biofilms by carboxy methyl chitosan combined with silver, zinc and copper salts", Int. J. Biol. Macromol., vol. 105, no. 1, pp. 385-392, 2017. https://doi.org/10.1016/j.ijbiomac.2017.07.048 
Nsimba et al., Int. Ann. Sci.; Vol. 10, Issue 1, pp: 45-51, 2021

[30] T. Deliopoulos, P. S. Kettlewell, M. C. Hare, "Fungal disease suppression by inorganic alts: a review", Crop Prot., vol. 29, no. 10, pp. 1059-1075, 2010. https://doi.org/10.1016/j.crop.2010.05.011

[31] D. G. Alvindia, K. T. Natsuaki, "Control of crown rotcausing fungal pathogens of banana by inorganic salts and a surfactant", Crop Prot., vol. 26, no. 11, pp. 16671673 ,

2007. https://doi.org/10.10.16/j.cropro.2007.02.008

[32] C. E. Bernard, M C. Harrass, M J. Manning, Chapter 94Boric acid and inorganic borate pesticides, Hatyes'Handbook Pestic. Toxicol. (Third Edition), pp. 2033-2053, 2010. https://doi.org/10.1016/B978-0-12374367-1.00094-X

[33] F. Darriet, B. Zumbo, V. Corbel, F. Chandre, "Influence des matières végétales et des engrais NPK sur la biologie de Aedes aegypti (Diptera : Culicidae)", Parasite, vol. 17, pp. 149-154, 2010. https://doi.org/10.1051/parasite/2010172149

[34] N. Mathew, M. G. Anitha, T. S. Bala, S. M. Sivakumar, R. Narmadha, M. Kalyanasundaram, "Larvicidal activity of Saraca indica, Nyctanthes arbor-tristis, and Clitoriaternatea extracts against three mosquito vector species", Parasitol. Res., vol. 105, no. 5, pp. 1017-1025, 2009. https://doi.org/10.1007/s00436-008-x

[35] J. H. Sukhthankar, H. Kumar, M. H. S. Godinho, A. Kumar, "Larvicidal activity of methanolic leaf extracts of plant, Chromolaena odorata L. (Asteraceae) against vector mosquitoes", Int. J. Mosq. Res., vol.1, no. 3, pp. 33-38, 2014.
Publish your research article in AIJR journals$\checkmark \quad$ Online Submission and Tracking

$\checkmark$ Peer-Reviewed

$\checkmark \quad$ Rapid decision

$\checkmark \quad$ Immediate Publication after acceptance

$\checkmark \quad$ Articles freely available online

$\checkmark \quad$ Retain full copyright of your article. Submit your article at journals.aijr.in

Publish your books with AIJR publisherPublish with ISBN and DOI $\checkmark$ Publish Thesis/Dissertation as Monograph. $\checkmark \quad$ Publish Book Monograph.

Publish Edited Volume/ Book.

$\checkmark \quad$ Publish Conference Proceedings $\checkmark \quad$ Retain full copyright of your books. Submit your manuscript at books.aijr.org 